\title{
Digitizing Archives in Russia: Epistemic Sovereignty and Its Challenges in the Digital Age
}

\author{
Alexey Golubev
}

\subsection{INTRODUCTION}

In March 2016, the Supreme Court of the Russian Federation examined a recent decision by the Ministry of Culture, the parent body of the Federal Archival Agency (Rosarhiv), to ban personal use of cameras, smartphones, and other technical devises for copying documents in Russian archives. During court hearings, a representative of the ministry argued that free and unlimited digitization without supervision by professional archivists would likely cause increased wear and damage to historical documents. She also argued that the current ban did not violate the right of free access to archival documents and hence to historical knowledge. This position received support from many professional archivists; one of their arguments was that, if unrestricted copying of archival materials was allowed, archives would be unable to guarantee the authenticity of copies, which, in turn, would lead to manipulations of historical evidence on a large scale. Nevertheless, the Supreme Court ruled that this decision was unlawful and it had to be repealed (Galanichev 2016, 299-300; Druzin 2018, 4-5).

I am grateful to David Brandenberger, Tatyana Doorn-Moisseenko, Joan Neuberger, Serguei Oushakine, the participants of the University of Houston Digital Research Commons lecture series, and the editors and reviewers of this volume for their insightful comments and suggestions that helped me improve this chapter.

\footnotetext{
A. Golubev (ه)

University of Houston, Houston, TX, USA

e-mail: avgolubev@uh.edu 
Archive users did not have much time to enjoy free and unlimited copying. In April 2016, Rosarhiv was transferred from the Ministry of Culture to the Presidential Administration of Russia, signifying that its head now reported directly to Vladimir Putin. Using its new legal status, in September 2017, the agency introduced a new regulation that allowed the use of personal cameras for copying, but only by permission (that could take days or even weeks) and for a fee. This regulation was challenged in the Supreme Court as well, but this time the court ruled that Rosarhiv did not violate any law and the practice of charging archive users for making digital copies with their own devices was legal (Kurilova 2019). As a result, Rosarhiv regained full control over the digitization of archival materials, even when it is done by private users for a personal purpose.

This story highlights the extent to which Russian state agencies and officials are concerned with digital reproducibility of historical documents as a phenomenon that challenges their control over the production of historical knowledge. According to the code and practice of Russian law, access to historical documents is a civil right, and while this right is routinely violated by state institutions, in many cases it has been successfully enforced through legal battles. At the same time, digitization of historical documents turned out to be a more controversial issue. The relative ease of the digital access and reproduction implies that online archives of historical documents can be not only produced at a low cost but also be available to a much bigger audience than before (for an example of such archives, see Chap. 21). This offers new opportunities in terms of communication of knowledge, but it also means that the circulation and production of historical knowledge becomes less centralized as it moves away from the expert-controlled domains such as edited volumes published by academic presses into a more egalitarian information society that trespasses national borders and jurisdictions where digital archives can be curated by virtually anyone. Given how important the maintenance of a coherent national narrative is for many Russian top officials (Brandenberger 2015, 200-205; Shteynman 2016, 107-108), it is unsurprising that Rosarhiv is very cautious when it comes to releasing the documents from its collections on the World Wide Web.

Yet the politics of history represent only one aspect of the current situation with digital archives in Russia. The unwillingness of Russian archives to outsource digitization of their materials means that when they start their own digitization projects, as a rule, they end up with high-cost solutions. An August 2018 post published by the Archival Committee of St. Petersburg in its Facebook group claimed that it took the archives fifteen years to digitize the parish register books of St. Petersburg; the same post claimed that a complete digitization of all collections of the St. Petersburg archives would require at least 45 billion rubles (ca. $\$ 650$ million at the current exchange rate) worth of funding and presumably decades of work (Archival Committee of St. Petersburg 2018). As a result, managers of Russian archives have to choose strategically which documents and collections should be presented online. Since most of 
the archives are chronically underfunded, they also actively solicit external funding both domestically and internationally in order to push forward their digitization efforts and get a better public outreach. The research and political agenda of funding agencies thus becomes part of the archival digitization process in Russia.

This chapter examines the production of digital archives in a broader context of the political economy of historical knowledge in Russia. The resolution of Rosarhiv to control which and how many documents its users copy digitally should be treated as a symptom signaling the epistemic anxieties of the state authorities. The archive, as the works of Michel Foucault, Jacques Derrida, Ann Stoler and many others have shown, is a key institution of the state power over history: it defines the dominant forms of knowledge, its limits and silences, establishes hierarchies of voices from the past, and produces experts with authority to interpret its documents. In other words, the archive is a powerful tool that transforms the totality of the historical experience preserved by a certain community or society into a structured hegemonic form that privileges some parts of this experience and silences other (Foucault 1977, 155-164; Foucault 2002, 146-148; Derrida 1996, 3-5, 10-13, 19-20; Stoler 2006, 44-51). However, modern information and communication technologies represent a formidable challenge to maintaining this epistemic sovereignty as they simplified to the extreme a precise reproduction of historical documents and production of digital archives, thus diluting the state's sovereign control over historical knowledge. The situation is further complicated by a relatively marginal place of Russian archives in the global economy of knowledge where the demand for the digitization of their materials often comes from outside of the Russian national borders and represents political and cultural interests of nonstate agents. As a result, a study of digital archives in Russia provides a unique perspective on the ways in which the Russian state adapts to the digital age.

This chapter starts with a discussion of the early digitization efforts during the 1990s and early 2000s that were largely funded by international funding agencies, most prominently the Open Society Institute, whose activity is presently banned in Russia. It then examines the growing concern of the state authorities over the reproduction of historical documents online and their efforts to control the production of digital archives through specialized funding agencies (such as the Russian Foundation for Humanities that in 2016 merged with the Russian Science Foundation) and restrictive measures. In the concluding section of the chapter I discuss the current state of digital archives in Russia, which is not limited to the activities of federal and international agencies, but also involves a great deal of private initiative. Yet despite the multitude of actors and large-scale digitization efforts, I argue, Russian digital archives are curated to conform to the dominant paradigms of historical knowledge and have so far failed to induce an epistemological shift in the studies of Russian history. 


\subsection{Archival Revolution: International Actors and Early Digitization EfForts}

The early effort to digitize historical documents from the former Soviet archives was an integral part of the archival revolution that started at the turn of the 1990s following the perestroika and led to an unprecedented openness of Russian archival collections for both the scholarly community and general public (Raleigh 2002). In Russia, this effort was spearheaded by international organizations. Between 1992 and 1996, for example, the Hoover Institution on War, Revolution, and Peace with the UK-based company ChadwyckHealey Ltd microfilmed approximately 14,500,000 pages of historical documents and inventory lists from the central Russian archives (Davies 1997, 101-102). In the mid-1990s, the Yale University Press launched the Annals of Communism book series with English translations of thousands of formerly classified documents of the Communist Party and the Soviet government. Another archival collection that attracted significant international interest in the early 1990s was the documents of the Third (Communist) International, or Comintern, stored in RGASPI (Rossijskij gosudarstvennyj arbiv social'nopolitičeskoj istorii, Russian State Archive of Social and Political History). Since the Comintern as an instrument of Soviet influence coordinated activities of Communist parties and affiliated groups in numerous countries between 1919 and 1943 , its records amount to 20 million pages written in multiple languages. The enormous size of these archive collections and imperfect inventory lists made their analysis complicated, as even a preliminary research required long-term trips to Moscow.

In 1992, the Council of Europe, the International Council of Archives and Rosarhiv initiated a discussion of a large-scale project that involved leading scholars on the history of the Comintern. The discussion aimed to prepare a large-scale project to create a database describing the entire Comintern collection at RGASPI (over 200,000 documents) and to digitize the key documents from the collection (ca. one million pages out of the total number of 20 million). In June 1996, the International Council of Archives and Rosarhiv signed a framework agreement that established the International Committee for the Computerization of the Comintern Archives (INCOMKA) under the auspices of the Council of Europe. The funding for this large-scale digitization project came from numerous sponsors, including many European archives, the Library of Congress, and the Open Society Archives. By 2003, the project was completed including $1,059,354$ digital images of archival documents (ca. $5 \%$ of the entire collection) and a searchable database of the entire collection with 239,602 entries (Doorn-Moisseenko 2005; Bachman 2005; Amiantov 2011).

Since the project was initiated at the dawn of the Internet era, the digital archive was initially hosted at the RGASPI without remote access, and its copies were distributed on CDs to the international project participants. Users had to be physically present at the RGASPI (a dedicated space was equipped with 17 workstations for this purpose) or in one of the partner institutions in order 
to work with the archive. However, by the time of the project completion in 2003 , this principle was already outdated, and the following year a joint venture company was formed by the Dutch academic publisher, IDC Publishers (purchased by Brill in 2006) and Russian corporation ELAR to provide paid online access to the dataset. This service was hosted at www.comintern-online. com and charged between 2000 and 7500 euro for an annual subscription depending on the buyer, with revenues shared between Rosarhiv, ELAR and IDC Publishers/Brill. The archive remained behind the paywall for the next ten years, until 2013, when it was published online as part of a new initiative The Documents of the Soviet Era of Rosarhiv that I will discuss later in this chapter.

The digital archive of the Comintern documents is a good example, illustrating the early stage of the digitization of Russian archives. The perestroika and the first post-Soviet decade in Russia were characterized by the state's temporary disinvestment in historical knowledge, and many national and international non-government agents sought to fill this gap proposing new epistemological models, producing new historical narratives, and publishing formerly classified documents, at first as books and then, as new information and communication technologies became increasingly widespread, as digital archives. The Open Society Institute (OSI) - a parent organization of the Open Society Archives which was one of the partner institutions of the INCOMKA projectwas the most visible actor in this sphere. Between 1996 and 2000, it granted a total of $\$ 1,500,000$ United States Dollars (USD) for different projects in the archival sphere, including the first website of Rosarhiv (Okhotin 2001). Before the Russian authorities forced the OSI to quit its activities in Russia, it supported such projects as online databases of the archival collections of the Russian State Documentary Film and Photo Archive (Bajgarova et al. 2000), Gorbachev Foundation (Kolesov 2002), National Archive of the Republic of Kareliâ (Kadymova and Kolesova 2003), and Perm' State Archive (Perm State Archive 2015). It was also one of the key sponsors of the society Memorial, a key non-government institution that publicizes knowledge about historical and contemporary state violence in Russia, that produced a database of the victims and later perpetrators of Soviet political repressions and several archives related to Soviet state violence, dissident movement, German forced labor, and oral history.

These projects had a clearly defined political agenda to educate audiences in Russia and abroad about the history of state violence, which was shared by many other international foundations that funded the digitization of archival documents in the post-Soviet countries. ${ }^{1}$ The goal to ensure a broad public outreach for these digital archives meant that they were produced as free products. A similar political agenda drove German research foundations to actively support the production of digital archives related to Soviet citizens' experience of Nazi violence during the Second World War. One of the latest projects of this kind is a digital archive of oral history interviews of former Soviet prisonersof-war and forced laborers Ta storona (Another Side) at tastorona.su. The 
archive is based on a collection of interviews of the society Memorial, and was funded by the German Foundation Remembrance, Responsibility and Future and the Henrich Böll Foundation, as well as OSI. Currently it provides access to 167 interviews using specially designed software that optimized the presentation of interview transcripts, their commentary, audiovisual and geospatial data, and meta descriptions (Beilinson 2015).

\subsection{Russian Archives and Commercial Content Providers}

The early stage of digitization of archival collections in Russia was also characterized by another trend: the commercialization of scholarly content. Histories of state violence in Russia were a particularly attractive subject for commercial publishers, but the trend was much bigger and included many other fields. The opening of Russian archives coupled with a huge economic gap between Russia and the First World nations during the 1990s created a situation when Western publishers were able to sign lucrative digitization agreements with Russian archives and libraries that granted them exclusive rights to distribute the resulting digital collections and archives worldwide. As a rule, Western partners provided equipment and funding for digitization, and Russian partners received digital copies of their collections that they could provide to users within their computer networks (although sometimes they retained the domestic distribution rights) as well as a percentage of sales.

The Dutch company IDC Publishers mentioned above in the context of the international distribution of the Comintern Digital Archive was one of the earliest and most active players in the digitization market of Russian historical documents and publications. It started producing Russia-related collections of primary sources for commercial distribution on microfiche long before the collapse of the Union of Soviet Socialist Republics (USSR) using books and periodicals from the Slavonic Library of the National Library of Finland. As early as in 1987, it signed contracts with the Russian National Library getting a priority access to its collection of periodicals, rare books, and historical documents (Russian National Library 2004, 17). Over the next twenty years, the IDC Publishers signed similar contracts with the Library of the Russian Academy of Sciences, K.D. Ushinsky State Scientific Pedagogical Library, Russian State Archive of Literature and Art, Russian State Military Archive, Moscow State University Library, and Russian State Archive of Social and Political History. Its team used the materials from these institutions to produce digital archives of the Artek Pioneer Camp (1944-1967), early Soviet cinema (1923-1935), Russian military intelligence on Asia (1651-1917), Jewish Theater under Stalinism, as well as extensive digital collections of Russian and Soviet periodicals. The company was remarkable for its careful market analysis, which, prior to its merger with Brill, allowed it to become a large and successful commercial content provider in the field of Russian studies, including in digital 
archives. However, following its merge with Brill in 2006, Russia- and Eastern Europe-related content lost its priority for the new company management. Access to the materials digitized earlier by the IDC Publishers is still sold through Brill either as an institutional subscription or as limited-term access for individual users (Doorn-Moisseenko 2019).

A similar model was used by the Yale University Press (YUP) in a collaboration agreement with the Russian State Archive for Social and Political History to digitize Joseph Stalin's personal archive (Fond 558). The project was initiated in the late 2000s with the financial support of $\$ 1,300,000$ from the Mellon Foundation (Mellon Foundation 2007), and in 2011 YUP launched the first version of the Stalin Digital Archive at www.stalindigitalarchive.com that over time grew to include 400,000 pages of over 28,000 documents including Stalin's personal papers, his domestic and international correspondence, and books with his marginalia. Access to the digital archive was provided through institutional subscription only. Rosarhiv as the parent organization of the RGASPI, however, retained the domestic distribution rights for the digitized copy of Stalin's archive, and launched its free version for Russia-based users in 2013 as part of the portal Documents of the Soviet Era at sovdoc.rusarchives.ru that I will discuss in the next section of the chapter.

Another example of a successful commercialization of digital archives of Russian historical documents and publications is represented by the East View Information Services, a Minnesota-based company founded in 1989 as the East View Publications, Inc. to distribute Soviet military journals for international audiences. Over the following three decades, it established itself as a major provider of digital content from Russia and other post-Soviet states as well as China, Afghanistan, Iran, and several African nations. Yet while for the latter regions its content is focused on exclusively contemporary affairs, its experience and expertise in the international distribution of Russian-language publications (one of its co-founders, Vladimir G. Frangulov, is a former research fellow at the Institute of World Economy and International Relations of the Russian Academy of Sciences) helped them diversify their business model by digitizing archives of Imperial-era, Soviet and post-Soviet periodicals and offering them as part of the subscription to their catalogue. The catalogue now includes digital archives of the key Soviet newspapers and magazines with a full-text search, which makes it particularly appealing for scholars (Lee and Frangulov 2014).

The fact that the archival revolution in Russia coincided with its transition to market economy and a subsequent crisis in the funding of state archives, on the one hand, and an astonishingly fast development of the new digitization technologies, on the other hand, opened a window of opportunity for Russian and Western non-governmental agents and for-profit companies to launch large-scale digital archive projects. In a way, they can be described as quasicolonial projects: exploiting economic inequality between Russian and the First World countries, they treated the Russian historical experience represented in these newly built digital archives as a commodity to be sold to the First World 
audiences (East View or Brill), or as a deviant experience, a lesson of what future generations had to avoid at all costs (the digital archives of the Comintern or Joseph Stalin). Yury Afanasyev, a professional historian who became an influential politician during the late-Soviet and early post-Soviet periods, characterized the unequal relationship between Russian archives and Western content providers in precisely these terms when he interpreted the aforementioned 1992 agreement between the Hoover Institution, Chadwyck-Healey Ltd, and Russian archives as a "typically colonial exercise" (Afanas'ev 1992). It is hardly surprising that, once the Russian state agencies were able to fund their own digitization projects, their political agenda became radically different.

\subsection{Russian Foundation for Humanities: Patching THe Archival Fabric}

Throughout the 1990s and into the early 2000s, domestic funding of archival digitizing activities in Russia had significantly lagged behind the projects supported by Western funding. It was only in 1994 that the Russian government established a specialized funding agency for social sciences and humanities, the Russian Foundation for Humanities (RFH), which had supported projects in digital humanities since 1995 (Semenov 1997, 118-119). However, limited funds and high costs of digitization activities kept them relatively small-scale: in 2015 , an average one-year grant in digital humanities was 500,000 rubles, or less than $\$ 10,000$ USD in that year's exchange rates (Blinov 2012, 235). Nevertheless, the Russian Academy of Sciences and universities have actively used this funding source to digitize and make available their archival collections, and a large number of small digital archives have appeared since the late 1990s. A typical project was, for example, a digital archive of ethnographic field records, a personal archive of a famous cultural figure or scholar, a collection of folklore texts and performances, or a digital archive of historical periodical. The number of documents in these archives typically numbered in hundreds, sometimes thousands, although the Russian Foundation for Humanities also supported multi-year projects that resulted in bigger digital archives. A full list of digital archives produced, thanks to the funding of the RFH, currently numbers in over a hundred, so below I will only focus on a few cases to illustrate the goals, scope, and implementation of such projects.

One of the early digital archives produced with the funding from the RFH was an online collection of audio records and transcripts of folklore performances of the Karelian Research Center (KRC) of the Russian Academy of Sciences. With the earliest records dating back to the 1930s, the collection represents critical knowledge of traditional music and performances among the ethnic groups of Northwest Russia, including Russians, Karelians, Vepsians, Finns, Izhorians, and Sami. In 1999, the KRC received funding to produce an online catalogue and to digitize sample records from both the Open Society Institute and the Russian Foundation for Humanities. An early version of the 
archive went online in early 2000 at phonogr.krc.karelia.ru; however, the number of actual records available online was just fourteen (Vdovicyn et al. 2000, 32-34). In 2008, the KRC received another grant from the RFH to make available transcripts of folklore texts recorded or written down by Soviet ethnographers, which resulted in the publication of over 400 original texts at folk. krc.karelia.ru. In 2012, yet another grant from the RFH allowed the center to add 70 audio records and their transcripts to the digital archive at phonogr.krc. karelia.ru/folklor. This amount represents a fraction of the records stored in the archive of the KRC, yet it provides valuable material for those scholars of the region and members of the general public who are interested in its traditional cultures. Similar projects have been implemented elsewhere in Russia, such as a digital archive of the folklore of the peoples of Siberia developed by the Siberian Branch of the Russian Academy of Sciences since 2014 folk.philology.nsc.ru, or a digital archive of ethnographic records from the Kaluga region of the Moscow Tchaikovsky Conservatory produced from a grant of the RFH in 2007 at folk.rusign.com.

The RFH also supported projects that sought to produce digital archives from fragmented collections, often in separate geographic locations, thus providing scholars and the general public with a single point of access to a certain periodical or a personal collection. The author of this chapter was a leading team member in one of such projects to create a digital archive of the surviving issues of the Russian imperial newspaper Oloneckie gubernskie vedomosti (OGV, or News of the Olonec Governorate). OGV was an official newspaper of the Olonec Governorate from 1838 to 1917; apart from official news and government decisions, it also published materials on history, economy, ethnography, and culture of Northwest Russia. By the mid-2000s, several libraries and archives in Petrozavodsk and St. Petersburg had partial collections of the newspaper, but in order to protect the fragile newspapers, most of them significantly restricted access to their collections (for example, the only categories of users who could work with the collection of the OGV issues from the library of the Karelian Research Center of the Russian Academy of Sciences were scholars with advanced degrees and graduate students). A digital archive of the newspaper simultaneously solved both problems by providing a consolidated collection of the surviving issues in free access. Given the complex logistics and a large scale of work, the RFH supported a three-year long project (2006-2008). It was implemented by a team from the Petrozavodsk State University, which digitized OGV issues from the National Archive of the Republic of Karelia, National Library of the Republic of Karelia, Academic Library of the Karelian Research Center, and Russian National Library in St. Petersburg. The result was a digital archive of initially 4670 issues of the newspaper (Golubev and Fotina 2007). After the completion of the project, it was maintained by the National Library of the Republic of Karelia that was able to digitize an additional 400 issues; as of now, the archive provides free access to 5064 issues at ogv.karelia.ru. Similar projects supported by the RFH include, among others, a digital archive of Ivan Bunin's personal papers at bunin-rgali.ru that 
consolidated the holdings of the Russian State Archive of Literature and Leeds Russian Archive Collections, and a digital archive of ethnographic records of field trips of the Moscow State University and St. Petersburg State University at ethnoarchive.spbu.ru. Apart from the Russian Foundation for Humanities and, since 2016, the Russian Science Foundation, similar small-scale digitization projects were supported by several federal and regional programs run by the Russian Ministry of Education and Russian Academy of Sciences.

\subsection{The Return of the State}

This system of grants run by the RFH helped to bring online many small archives of Russian universities and institutes of the Academy of Sciences, but at the same time it had a priori too limited a scope to engage in a large-scale digitization of archival collections of the central and regional Russian archives. The latter work became possible due to a particular conjunction of state and business interests in Russia. In 2002, the Russian government launched a federal program called Elektronnâa Rossiâ (Electronic Russia) with the goal to accelerate the use of new information and communication technologies in state administration. The program was designed for the period of 2002-2010, and while it failed to achieve the original goal to create a comprehensive online access to state services, one of its by-products was the appearance of a new segment in the Russian Information Technologies (IT) market, namely, a stable demand for commercial solutions in the sphere of e-governance. Among the companies that benefited from the new market conditions was Electronic Archive Corp. (ELAR). Established in 1992, it specialized in developing and providing of highly automated digitization technologies, and after 2002 it became the leading contractor of Russian government agencies, including Rosarhiv, in such areas as digitization of archives, development of digitization hardware and software, and digital archive management systems (Plotnikov 2014). Unlike Western commercial publishers and content providers such as Brill and EastView, ELAR uses a different business model: namely, state contracts to produce digital archives. In this model, Rosarhiv has a full authority over the selection of the content, and ELAR as the contractor does not acquire any distribution rights for the digitized content, which is published in open access. Since its profits come exclusively from the amount of completed work, its management is interested in lobbying more projects with the Russian government and its agencies, which has become an important driving force in the digitization of Russian archives.

The digital archives produced, at least partially, within this model include Rosarhiv's Documents of the Soviet Era and The People's Memory contracted by the Russian Ministry of Defense. Documents of the Soviet Era was launched in 2013 at sovdoc.rusarchives.ru and from the very beginning comprised several earlier document collections, namely, the aforementioned digital archives of the Comintern and of Joseph Stalin. According to the agreement with the Yale University Press, the website restricts access to Stalin's archive from 
non-Russian and non-Belorussian Internet protocol (IP) addresses. At the same time, several document collections were digitized exclusively for this project, including 30,000 electronic copies of documents of the Politbûro for 1919-1932 (May 2013), 240,000 electronic copies of documents of the Soviet State Defense Committee (June 2015), 122,000 copies of documents about the Russian Revolution of 1917 (December 2017), and several smaller collections. In his interviews, the current head of Rosarhiv Andrej Artizov repeatedly emphasized that the purpose of the digital archive was to educate national audiences about the complexity of the Soviet period of Russian history (Artizov 2018). In doing so, the management of Rosarhiv-which in these contexts represents the historical profession as such-asserts its authority in the production of knowledge about Russian history, thanks to the seemingly comprehensive nature of their digital archive as well as vast possibilities to enlarge it by digitizing additional materials when necessary. Rosarhiv has used this positionality in order to advance the state's agenda in such questions as the legitimacy of Russia's annexation of Crimea, the treat of Ukrainian nationalism, and the complacency of Britain and France in the rise of Nazism in Europe, with the publication of digital copies of historical documents serving as a technique to challenge the widespread accusations of illegitimacy of Russia's claims for Crimea, the Ukrainian claims that the Holodomor was an intentional act of genocide against the Ukrainians, and of the critical role of the MolotovRibbentrop Pact in provoking the outbreak of the Second World War (Artizov 2014, 7-10; Brandenberger 2015, 202-203).

The management of Rosarhiv places a special emphasis on its comprehensive approach to the digital publication of archival documents: instead of handpicking sources to highlight certain aspects of the Soviet historical experience, Rosarhiv chose to make available entire document collections. In the logic of their creators, this approach should produce a more credible picture of the historical past than the partial digital archives of Vladimir Bukovskij (bukovskyarchives.net), Aleksandr Yakovlev (www.alexanderyakovlev.org), and Dmitrij Volkogonov's collection in the Library of Congress (National Security Archive 2017). Their authors, who at one or another point in the late 1980s and 1990s acquired access to classified collections of Russian archives, understandably focused on more sensational and controversial documents (Bukovskij 1996, 51-63). Yet, while providing authentic copies of important historical documents, these digital collections fail to present the totality of Soviet decisionmaking at the top level that the Documents of the Soviet Era can claim.

Needless to say, this claim of totality and objectivity disguises the epistemic and political foundations of the actual archival collections in the possession of Rosarhiv (Rosenberg 2001, 82-84). Moreover, while its management and staff are concerned with the questions of epistemological sovereignty, their understanding of how to "decolonize" Russian history is framed primarily in terms of data management with archives performing the function of a mediator, but also a censor, between historical documents and professional historians. This logic is based on the understanding of historical documents deposited in 
archives as the most authentic and epistemologically reliable evidence about the Russian past, which is why, for example, Artizov argues that the production of digital archives such as the Documents of the Soviet Era is the best strategy to refute "false" interpretations of Russian history (Artizov 2014, 7). What is missing in this understanding is that the documents themselves do not provide new knowledge, but instead replicate the same interpretive categories that were laid in the foundation of original archival collections with their explicit and hidden hierarchies, silences, gaps, and exclusions.

The corporation ELAR played a key role in the development of another digital archive called The People's Memory at pamyat-naroda.ru that combines archival data and copies of original documents related to Soviet servicemen during the Second World War. The archive is based on the collections stored in the Central Archive of the Russian Ministry of Defense, and currently includes digital copies of 425,000 original documents. Its structure is much more complex than that of the Documents of the Soviet Era: in addition to presenting electronic copies of historical documents, the developers of the archive extract biographical data from them and combine personal information from various sources into coherent biographies. The archive also provides access to ca. 100,000 digitized military maps to trace the movements of Soviet detachments and servicemen during the war, and a rich collection of original battle reports. Currently, the development team collaborates with German archives to add to The People's Memory information about Soviet prisoners-of-war. The officially postulated goal of this archive is, like in the case of the Documents of the Soviet Era, to build up a critical mass of documentary evidence so that an unbiased and objective understanding of the Soviet Union's participation in the Second World War would appear as a result of free access to these documents. At the same time, apart from epistemic concerns, this project also has an important humanitarian mission: to help the relatives of the Soviet servicemen to find relevant biographic information about their lives and deaths.

\subsection{Vernacular Archives}

In recent years, thanks to the ongoing digital revolution that makes digitization technologies increasingly cheap and easy to use, this discrepancy was addressed when a new phenomenon appeared that can be characterized as vernacular digital archives: namely, projects created, maintained, and supported by volunteers who are driven by a desire to preserve those aspects of the Russian historical experience that have been neglected due to a lack of funding or interest by the state archives. Two prominent projects include a digital archive of Soviet-era radiobroadcasts Audiopedia at audiopedia.su and a digital archive of diaries Prozhito at prozhito.org (for more, see Chap. 21). Audiopedia grew from an earlier project Staroe Radio (Old Radio, staroeradio. ru), when in 2007 Yury Metelkin, a former Soviet rock-musician, launched an online radio station that broadcast Soviet-era programs, including audiobooks, audio-plays, science broadcasts, and so on. Over the following years, the 
archive of Staroe Radio grew through the efforts of volunteers who digitized their old records and donated them to Metelkin; in 2018, it acquired an entire archive of the Irkutsk radio station that includes federal and local records from the 1940s on, or ca. 80,000 phonograms. Prozhito is a later project that dates back to 2015 when its founder, Mikhail Melnichenko, decided to produce a historical corpus of texts that could be used to trace the use of certain concepts. The project employs a large group of volunteers to identify, scan, process, and upload diary entries (Nordvik 2018, 43-44); as of early 2019, it provides access to nearly 3000 diaries, mainly from the Soviet era.

Both Audiopedia and Prozhito are non-commercial and non-government projects, and as such they show a large potential of public and digital history in terms of preserving and communicating historical evidence. Yet both ultimately work within the same paradigm of history as a national project that the Documents of the Soviet Era and The People's Memory are part of. Metelkin explicated this logic in his explanation of why he decided to preserve, digitize, and make available old radio broadcasts, mentioning the "preservation of the [national] language, education, cultural traditions, and ultimately national selfidentity" - or everything that is traditionally identified as functions of state power-as the driving factors of his project. The very fact that both projects inadvertently prioritize the experience of the Soviet educated class, that is, the people who are more likely to internalize and embody the national agenda, means that the digital technologies do not challenge the logic of the national archive but rather ensure a better and more effective communication of knowledge produced through it to national audiences.

\subsection{Conclusion}

The examples discussed above show that the Russian state has sought to use digital archives to firmly re-establish itself through its institutions (primarily Rosarhiv) as the main authority in the production of knowledge of Russian history, especially during the Soviet period, which remains extremely contested. Symptomatically, other post-Soviet states have used similar strategies: for example, Latvia whose government has persistently interpreted the period between 1940 and 1991 as an experience of double (Soviet and Nazi) occupation has recently made accessible documents of the Latvian office of the KGB (Komitet gosudarstvennoj bezopasnosti, Committee for State Security) at kgb. arhivi.lv with the names of its agents. The online publication of these documents by the State Archives of Latvia follows the same logic as the development of digital archives in Russia. The digitization of historical documents remains an expensive business that the state agencies and non-governmental organizations (NGO) use strategically to create an online presence of document collections that, from their perspective, benefit the common good, the understanding of which can vary dramatically from the national interests to global human rights to objective knowledge. 
The archival revolution of the early 1990s and the fact that it was used by a number of international actors (Library of Congress, Hoover Institution, IDC Publishers, etc.) to reproduce valuable collections of historical sources put Russian government bodies such as Rosarhiv and the Ministry of Defense in a situation where, despite their full control of the most important archival collections from Russian and Soviet history, they had to take proactive steps to act as the authoritative sources of critical evidence about Russian history. They responded to this challenge with ambitious digitization programs that provided an unprecedented level of access to primary sources in Russian history. At the same time, the political and epistemic concerns that drove the production of these archives forced their patrons and developers to concentrate on a very narrow list of topics that is limited to political and military history. Grants for digital projects provided by the RFH addressed a broader number of themes in social, cultural, and intellectual history, but in a very fragmentary manner due to limited funding.

The digital reproduction of historical documents and their communication online thus performs largely the same functions as the traditional archive, namely, maintaining state sovereignty over history, reinforcing silences in dominant historical narratives, and endowing certain groups of experts with the authority to define the authenticity and validity of selected facts and sources. Even though such a phenomenon as the vernacular archive has become increasingly prominent in recent years, it has yet to challenge this situation, since the developers of these digital archives have so far followed the preexisting structures and hierarchies of knowledge that prioritize the historical experience of privileged political and social groups.

\section{Note}

1. For example, during 2006-2007, the author was an investigator of the project Missing in Karelia: Canadian Victims of Stalin's Purges funded by the Canadian Social Sciences and Humanities Research Council (principle investigator Prof. Varpu Lindström of York University). The project resulted in a database of Finnish-Canadian and Finnish-American immigrants to the Soviet Union that compiled information from several thousand of archival documents from the National Archive of the Republic of Karelia (http://missinginkarelia.ca/, accessed December 13, 2013); after the domain name expired in December 2013, the digital archive was deposited by the National Archives of Finland and the National Archive of the Republic of Karelia (currently unavailable online).

\section{REFERENCES}

Afanasyev, Yury. 1992. Arhivnaâ 'Berëzka' [Archives as a Hard Currency Shop]. Komsomol'skaâ pravda, May 23.

Amiantov, Ju.N. 2011. Dokumenty sovetskoj èpohi. Istoriâ i sovremennost'. K 90-letiû Rossijskogo gosudarstvennogo arhiva social'no-političeskoj istorii [Documents of 
the Soviet Era. History and the Present. To the 90-Year Anniversary of the Russian State Archive of Socio-Political History]. Vestnik arhivista 1: 192-198.

Archival Committee of St. Petersburg. 2018. Mif \#l: Nado ocifrovat' i vyložit' v Internet vse dokumenty [Myth No. 1: All Documents Must be Digitized and Published Online]. Archives of St. Petersburg, a Facebook Group. https://www.facebook.com/spbarchives/posts/1126231160858846.

Artizov, A.N. 2014. Obŝestvennaâ missiâ rossijskih arhivov [The Social Mission of Russian Archives]. Otě̌estvennye arhivy 5: 3-11.

- 2018. Â blagodaren arhivistam za ih samootveržennyj trud [I Am Grateful to Archivists for Their Selfless Work]. Otě̌estvennye arbivy 1: 3-6.

Bachman, Ronald D. 2005. The Comintern Archives Database: Bringing the Archives to Scholars. Slavic \& East European Information Resources 6 (2-3): 23-36.

Bajgarova, N.S., Ju. A. Buhshtab, and N.N. Evteeva. 2000. Sovremennaâ tehnologiâ soderžatel'nogo poiska v èlektronnyh kollekciâh izobraženij [Current Technologies of Content Search in Digital Collections of Images]. Meždunarodnaâ konferenciâ EVA 2000 Moskva: Èlektronnye izobraženiâ $i$ vizual'nye iskusstva [International Conference EVA 2000. Moscow: Digital Images and the Arts]. October 30November 3,2000. http://www.artinfo.ru/eva/EVA2000M/eva-papers/200008/ Baigarova-R.htm.

Beilinson, Daniel. 2015. Publish Interactive Historical Documents with Archivist. Medium, September 14. https://medium.com/@_daniel/publish-interactivehistorical-documents-with-archivist-7019f6408ee6.

Blinov, A.N. 2012. Rossijskij gumanitarnyj naučnyj fond i sociogumanitarnye issledovaniâ v sovremennoj Rossii [Russian Foundation for Humanities and Social Sciences and Humanities in Russia]. Vestnik MGIMO-Universiteta 2 (23): 231-236.

Brandenberger, David. 2015. Promotion of a Usable Past: Official Efforts to Rewrite Russo-Soviet History, 2000-2014. In Remembrance, History, and Justice: Coming to Terms with Traumatic Pasts in Democratic Societies, ed. Vladimir Tismaneanu et al., 191-212. Budapest: Central European University Press.

Bukovskij, Vladimir. 1996. Moskovskij process [The Moscow Hearings]. Moscow: MIK.

Davies, R.W. 1997. Soviet History in the Yeltsin Era. London: Palgrave Macmillan.

Derrida, Jacques. 1996. Archive Fever: A Freudian Impression. Translated by Eric Prenowitz. Chicago: University of Chicago Press.

Doorn-Moisseenko, Tatiana. 2005. The Comintern Archives Online. In Virtual Slavica: Digital Libraries. Digital Archives, ed. Michael Neubert, 37-44. Binghamton, NY: Haworth Information Press.

Doorn-Moisseenko, Tatyana. 2019. Interview by Alexey Golubev. By Skype. Houston, TX, March 2.

Druzin, M.V. 2018. Otečestvennye arhivy i pol'zovateli: problemy vzaimootnošenij v načale XXI veka [Russian Archives and Their Users: Communication Problems at the Beginning of the 21st Century]. Istoricheskij kur'er 2: 13. http://istkurier.ru/ data/2018/ISTKURIER-2018-2-13.pdf.

Foucault, Michel. 1977. Nietzsche, Genealogy, History. In Language, Counter-Memory, Practice, ed. Michel Foucault, 139-164. Ithaca, NY: Cornell University Press.

- 2002. Archaeology of Knowledge. London: Routledge.

Galanichev, A.V. 2016. K arhivam primenim zakon 'O zaŝite prav potrebitelej' [The Consumer Protection Law is Applicable to Archives]. Istoričeskaâ èkspertiza 3: 295-301. 
Golubev, A.V., and Je.V. Fotina. 2007. Polnotekstovaâ informacionno-poiskovaâ sistema 'Oloneckie gubernskie vedomosti' [Full-Text Storage and Retrieval System 'News of the Olonets Governorate']. Innovacii v usloviâh razvitiâ informacionnokommunikacionnyh tehnologij, 354-355. Conference Proceedings, Sochi, October 1-10. Moscow: MIEM.

Kadymova, O.P., and V.G. Kolesova. 2003. Evropejskie proekty IST v oblasti arhivnogo dela i rossijskie arhivy v seti Internet [European IT Projects in Digital Archives and Russian Archives on the Web]. Cultivate-Russia, 2, February. https://www.itweek. $\mathrm{ru} / \mathrm{idea} /$ article/detail.php? ID=60636.

Kolesov, Andrej. 2002. Avtomatizirovannaâ sistema Gorbačev-Fonda [Software of the Gorbachev Foundation]. itWeek, 323, May 2002. https://www.itweek.ru/idea/ article/detail.php? ID=60636.

Kurilova, Anastasija. 2019. Den'gi sdadut v arhiv: VS otklonil isk k Rosarhivu ob otmene platy za kopirovanie dokumentov [Cash to be Deposited in the Archive: The Supreme Court Declined a Case against Rosarhiv to Stop Charging for Document Copying]. Kommersant, November 22, 2018. https://www.kommersant.ru/ doc/3807340.

Lee, Kent D., and Vladimir G. Frangulov. 2014. East View Information Services Celebrates 25 Years in Business. Slavic \& East European Information Resources 15 (4): 247-254.

Mellon Foundation. 2007. Digital Stalin Archive [Rosarhiv]. Grant Database, https:// mellon.org/grants/grants-database/grants/yale-university/40700616/.

National Security Archive. 2017. Kollekcija Volkogonova. https://nsarchive2.gwu. edu/rus/Volkogonov.html.

Nordvik, Vladimir. 2018. Èto 'prozhito' ne zrâ! [This 'Prozhito' is Valuable!]. Rodina 8: 42-53.

Okhotin, N.G. 2001. Institut 'Otkrytoe obŝestvo (Fond Sorosa) v podderžku rossijskih arhivov (1996-2000) [Open Society Institute (Soros Foundation) and Its Support of Russian Archives]. Vestnik arhivista 2 (2001): 89-92.

Perm State Archive. 2015. Istoriâ arhiva [History of the Archive]. http://www.archive. perm.ru/about/history.php.

Plotnikov, Pavel. 2014. Sodejstvovat' informacionnomu progressu obŝestva i gosudarstva [To Contribute to the IT Progress of the Society and State]. Innovacii 2 (184): 102-106.

Raleigh, Donald J. 2002. Doing Soviet History: The Impact of the Archival Revolution. The Russian Review 61, no. 1 (January): 16-24.

Rosenberg, William. 2001. Politics in the (Russian) Archives: The 'Objectivity Question,' Trust, and the Limitations of Law. The American Archivist 64 (1): 78-95.

Russian National Library. 2004. Fevral' 2004 g. Hronika [February 2004: News Bulletin]. St.Petersburg: RNL. http://nlr.ru/news/rnbinfo/2004/2-3.pdf.

Semenov, Evgeny V. 1997. Ponât' učënogo [To Understand a Scholar]. Vestnik Rossiiskoi akademii nauk 67 (2): 118-124.

Shteynman, Maria. 2016. Political Myth and Political Glory: Shaping Media Reality. Russian Sociological Review 15 (4): 96-113.

Stoler, Ann. 2006. Along the Archival Grain: Epistemic Anxieties and Colonial Common Sense. Princeton: Princeton University Press. 
Vdovicyn, V.T., V.P. Kuznecova, A.A. Bedorev, N.B. Lugovaja, S.M. Rusakov, and A.D. Sorokin. 2000. Sozdanie èlektronnoj versii arhiva fol'klornoj fonoteki IÂLI KarNC RAN [Development of the Digital Archive of the Folklore Phonogram Collection of the Institute of Language, Literature and History of the Karelian

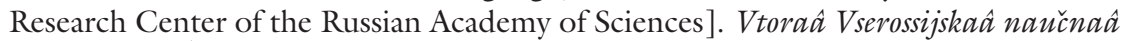
konferenciâ "Elektronnye biblioteki: perspektivnye metody i tehnologii, èlektronnye kollekcii,” 32-38. Conference Proceedings, Protvino, September 26-28.

Open Access This chapter is licensed under the terms of the Creative Commons Attribution 4.0 International License (http://creativecommons.org/licenses/ by/4.0/), which permits use, sharing, adaptation, distribution and reproduction in any medium or format, as long as you give appropriate credit to the original author(s) and the source, provide a link to the Creative Commons licence and indicate if changes were made.

The images or other third party material in this chapter are included in the chapter's Creative Commons licence, unless indicated otherwise in a credit line to the material. If material is not included in the chapter's Creative Commons licence and your intended use is not permitted by statutory regulation or exceeds the permitted use, you will need to obtain permission directly from the copyright holder. 